\title{
Grafting Tomato to Manage Bacterial Wilt Caused by Ralstonia solanacearum in the Southeastern United States
}

C. L. Rivard, Department of Plant Pathology, S. O'Connell and M. M. Peet, Department of Horticultural Science, and R. M. Welker and F. J. Louws, Department of Plant Pathology, North Carolina State University, Raleigh 27695

\begin{abstract}
Rivard, C. L., O’Connell, S., Peet, M. M., Welker, R. M., and Louws, F. J. 2012. Grafting tomato to manage bacterial wilt caused by Ralstonia solanacearum in the southeastern United States. Plant Dis. 96:973-978.

Bacterial wilt, caused by Ralstonia solanacearum, can result in severe losses to tomato (Solanum lycopersicum) growers in the southeastern United States, and grafting with resistant rootstocks may be an effective strategy for managing this disease. However, $R$. solanacearum populations maintain considerable diversity, and little information is known regarding the efficacy of commercially available rootstocks to reduce bacterial wilt incidence and subsequent crop loss in the United States. In this study, tomato plants grafted onto 'Dai Honmei' and 'RST-04-105-T' rootstocks had significantly lower area under the disease progress curve (AUDPC) values compared with nongrafted plants $(P<0.05)$. Across three locations in North Carolina, final bacterial wilt incidence for non- and self-grafted plants was $82 \pm 14$ to $100 \%$. In

$21 \%$. Final bacterial wilt incidence of plants grafted with Dai Honmei rootstock was 0 and $13 \pm 3 \%$ at two locations in western North Carolina but $50 \pm 3 \%$ at a third site in eastern North Carolina. Similarly, grafting onto RST-04-105-T rootstock significantly reduced AUDPC values at two of the three locations $(P<0.05)$ compared with that of the nongrafted plants, but performed poorly at the third site. Total fruit yields were significantly increased by grafting onto resistant rootstocks at all three sites $(P<0.05)$. Regression analyses indicated that yield was significantly negatively correlated with bacterial wilt AUDPC values ( $R^{2}$ was 0.4048 to 0.8034$)$, and the use of resistant rootstocks enabled economically viable tomato production in soils naturally infested with $R$. solanacearum.
\end{abstract} contrast, bacterial wilt incidence for the grafted plants was 0 to $65 \pm$
Bacterial wilt, caused by Ralstonia solanacearum, can be a significant problem for tomato growers that have infested soils because of the complex biology of the pathogen, potential severity of the disease, and lack of effective management strategies $(3,13) . R$. solanacearum infects tomato (Solanum lycopersicum) roots through wounds or natural openings, colonizes the xylem, and produces extracellular polysaccharides that clog the vascular tissue (15). Ultimately, this prevents movement of water up through the stem, and total collapse of the plant may occur in 2 to 5 days (26). This disease can cause severe yield losses $(3,13)$, and the presence of the pathogen often results in growers abandoning infested fields for tomato production.

$R$. solanacearum has a host range of more than 50 plant families (21) and maintains considerable diversity worldwide $(13,21,37,41)$. The bacterium can infect several solanaceous crops, including tomato, pepper, potato, eggplant, and tobacco (13). R. solanacearum is also metabolically versatile, surviving in diverse habitats such as water and soil and, latently, in infected plants (13). It is also easily dispersed and can move into noninfested areas through water, soil, and infected plant material, and by mechanical means $(3,6,13,21,26,35)$. The world population of $R$. solanacearum is

Corresponding author: Frank J. Louws, E-mail: frank_louws@ncsu.edu

Current address of C. L. Rivard: Kansas State University, Department of Horticulture, Forestry, and Recreation Resources, Manhattan 66506.

Current address of M. M. Peet: National Institute of Food and Agriculture, United States Department of Agriculture.

Mention of a trademark, proprietary product, or vendor does not constitute a guarantee or warranty of the product and does not imply its approval to the exclusion of other products or vendors that also may be suitable.

Accepted for publication 26 December 2011.

http://dx.doi.org/10.1094/PDIS-12-10-0877

(C) 2012 The American Phytopathological Society separated into four biovars (14) and three races (3), and has recently been classified into phylotypes and sequevars (9). In the southeastern United States, phylotype II, sequevar 7 (formerly biovar 1) is of greatest importance and occurs endemically $(9,26)$.

Control of bacterial wilt is difficult for tomato growers in the southeastern United States, particularly for growers with limited capacity to rotate out of solanaceous crops. The wide host range of $R$. solanacearum (21) further restricts rotational options, and effective crop rotation programs in severely infested soils may require multiple years out of tomato production (23). Even soil fumigants have little success against this pathogen $(7,8)$, and vertical movement of $R$. solanacearum in soils (35) may allow the bacterium to recolonize fumigated beds quickly.

Host resistance could be a useful option for managing bacterial wilt but numerous challenges exist for plant breeders. Resistance to bacterial wilt in tomato is quantitative, and is strongly influenced by environmental conditions such as soil temperature, $\mathrm{pH}$, and moisture (37). Even when resistance is effective, it is typically strain specific $(12,41)$, and the diversity of pathogenic strains of $R$. solanacearum has led to the development of resistant lines that are not durable over diverse geographic regions (36). Another issue that has been problematic for tomato breeders is that small fruit size is linked to resistance to bacterial wilt $(29,40,41)$. One way to circumvent this problem is by grafting cultivars that have good fruit production characteristics onto bacterial wilt-resistant rootstocks.

Grafting has been utilized to manage bacterial wilt in tomato crops worldwide $(11,24,25,30,39)$, and has been proposed recently in the United States for open-field and high-tunnel production (22,33). Breeding lines CRA 66 and Hawaii 7996 were found to significantly reduce bacterial wilt incidence in naturally infested soils in North Carolina (33). Although these findings are important for the implementation of rootstock breeding programs in the United States, they do not provide information that is readily useable for growers who face this devastating disease. Rootstocks that provide resistance to bacterial wilt are available from commercial seed companies (32). However, the ability of these rootstocks to confer resistance against native $R$. solanacearum strains in the United States is currently unknown. 
Because grafting could be a valuable tool for tomato growers in the southeastern United States, it is of critical importance to evaluate rootstocks that are readily available to growers for resistance to strains of $R$. solanacearum present in the southeastern United States. Therefore, the objectives of this study were to (i) evaluate commercially available tomato rootstocks for the ability to reduce the incidence and severity of tomato bacterial wilt in North Carolina and (ii) determine whether any conferred resistance results in increased tomato fruit yield.

\section{Materials and Methods}

Trials were established at one location in 2007 (Sampson County, NC) and two locations in 2009 (Jackson and Henderson Counties, NC). Each trial was conducted as a randomized complete block design with four replications. As is typical for the region, raised-bed plasticulture was employed with a stake-and-weave plant-training system (16). Water was provided by drip irrigation and soil fertility was managed according to standard on-farm protocols (described below).

Bacterial wilt ratings were performed throughout the course of the growing season by observing symptoms of the disease on the tomato plants. Disease incidence was recorded based on the presence of $R$. solanacearum detected by isolation as well as visible symptoms of bacterial wilt on the host, as described below. Symptoms of bacterial wilt included a complete loss of turgor and total plant collapse (26). Once plant collapse had occurred, all remaining fruit on the plant were harvested and each plant was dissected in order to assess whether $R$. solanacearum was present within the stem. Stem segments $(2.5 \mathrm{~cm}$ long) of wilted plants were excised, surface sterilized in commercial bleach solution $(0.5 \%$ sodium hypochlorite) for $2 \mathrm{~min}$, rinsed in sterilized water, and used to isolate $R$. solanacearum from affected plants onto Kelman's TZC semiselective agar medium (20). Excised stems of symptomatic plants were also subjected to an Rs Immunostrip (Agdia, Elkhart, IN) assay to verify the presence of $R$. solanacearum.

Transplant production and grafting. All grafted and nongrafted tomato transplants were produced at the Southeastern Plant Environment Laboratory located at North Carolina State University (Raleigh; http://www.ncsu.edu/phytotron/). 'Celebrity' (Harris Seeds; Rochester, NY) and 'Mountain Fresh' (Harris Seeds) were used as the scion cultivar for rootstock treatments, and for non- and self-grafted control treatments in 2007 and 2009, respectively. Scions were chosen based on preference of the on-farm collaborators to represent a cultivar typically used by each grower for their specific market. Both are hybrid cultivars with determinate growth patterns, are commonly used for open-field production, and have no known resistance to bacterial wilt $(26,37)$. Celebrity was used in the Sampson County trial and Mountain Fresh was used at the Jackson and Henderson County locations.

Commercially available rootstocks 'RST-04-105-T' (DP Seeds; Yuma, AZ), 'Dai Honmei' (Asahi Industries Co.; Saitama, Japan), and 'TMZQ702' (Sakata Seed; Yokohama, Japan), and one currently unreleased line, 'DR-BW-NCS2' (De Ruiter Seeds, Bergschenhoek, The Netherlands), were utilized for rootstock treatments in these studies. In the Sampson and Jackson County trials, a self-grafted treatment was included where the scion cultivar was grafted onto the original root system to account for any grafting or healing effects. The Japanese top-grafting, or tube grafting, method was utilized for all grafted plants (32). Rootstock and scion seedling stems were severed and then held together using a silicon clip. Once grafted, the plants were immediately moved into a "healing chamber" where humidity and light conditions were manipulated to promote graft union formation (32).

Sampson County trial. A field trial was conducted in 2007 at a commercial organic farm located in the Coastal Plain region in Sampson County, NC (34.6138069 N, 78.2458362 W). The soil type was a Chipley sand ( $\mathrm{pH}$ 6.0). This farm was certified for organic production, and fields had been taken out of tomato production in 2002 due to recurring crop failures from severe bacterial wilt pressure (28). In 2007, the grafting treatments included Celeb- rity grafted onto Dai Honmei and RST-04-105-T rootstocks, in addition to non- and self-grafted Celebrity.

The trial was conducted in two 34-m-long rows (two blocks/ row) and the grafting treatments were randomly assigned to $3.7-\mathrm{m}-$ long plots within each of the four blocks. Seven plants were located within each plot, and cultural methods were consistent with typical on-farm tomato production in this region of North Carolina. Plants were spaced $53 \mathrm{~cm}$ apart within the row and rows were 1.5 $\mathrm{m}$ wide. Preplant nitrogen was supplied through incorporation of a rye (Secale cereale) and vetch (Vicia villosa) cover crop and a supplemental feathermeal (12-1-0) application of $\mathrm{N}$ at $161 \mathrm{~kg} / \mathrm{ha}$. Potassium was applied as $\mathrm{K}$ at $50 \mathrm{~kg} / \mathrm{ha}$ through a preplant application of $\mathrm{K}_{2} \mathrm{SO}_{4}$. The Sampson County experiment was initiated on 20 April 2007. Harvesting was carried out on 18, 22, 26, and 30 June; 4, 10, 14, 19, 26, and 31 July; and 3 and 8 August. All tomato fruit were harvested and graded as marketable or nonmarketable based upon on-farm standards. Fruit weight and number were recorded for each grade.

Jackson County trial. A field trial was conducted in 2009 at a commercial farm located in the western mountain region in Jackson County, NC (35.4227163 N, 83.3082677 W). The soil type was a Braddock clay loam ( $\mathrm{pH}$ 6.5). This field had repeated crop failures due to severe bacterial wilt pressure in one particular area (approximately 0.5 ha in 2008). The grafting treatments included Mountain Fresh grafted onto Dai Honmei and RST-04-105-T rootstocks, in addition to non- and self-grafted Mountain Fresh.

The Jackson County trial was conducted on two 29-m-long rows (two blocks/row). The grafting treatments were randomly assigned to 3.2-m-long plots within each of the four blocks. Seven plants were located within each plot, and cultural methods were consistent with on-farm tomato production for this region. Plants were spaced $46 \mathrm{~cm}$ apart within the row and rows were $1.5 \mathrm{~m}$ wide. Blended preplant fertilizer (8-3-20) was applied as $\mathrm{N}$ at $54 \mathrm{~kg} / \mathrm{ha}$, and two $\mathrm{Ca}\left(\mathrm{NO}_{3}\right)_{2}$ fertigation events were supplied as $\mathrm{N}$ at 67 $\mathrm{kg} / \mathrm{ha}$ on 30 July and 17 August. The Jackson County trial was initiated on 21 July 2009. Fruit was harvested on 23 and 29 September, and 6 and 15 October. All tomato fruit were harvested and graded as marketable or nonmarketable based upon on-farm standards, and fruit weight and number were recorded for each grade. On the final date, all fruit larger than $5 \mathrm{~cm}$ were harvested and recorded.

Henderson County trial. A field trial was conducted in 2009 at the Mountain Horticultural Crops Research and Extension Center (http://www.agr.state.nc.us/research/mhcrs.htm) in Henderson County, NC (35.4267596 N, 82.5574439 W). The soil type was a Elsinboro loam ( $\mathrm{pH}$ 6.4). The grafting treatments included Mountain Fresh grafted onto Dai Honmei, RST-04-105-T, DR-BWNCS2, and TMZQ702 rootstocks, in addition to nongrafted Mountain Fresh. In this study, a self-grafted treatment was not included due to limited field space. A previous study showed that self-grafting did not significantly affect the incidence of bacterial wilt (33).

The trial was conducted on $2015-\mathrm{m}$-long rows (one plot/row), with 12 plants of each treatment located within the center of the row. Plants were spaced $46 \mathrm{~cm}$ apart within the row and rows were $1.5 \mathrm{~m}$ wide. The grafting treatments were randomly assigned to each row within a given block and rows were $1.5 \mathrm{~m}$ apart. Blended preplant fertilizer (13-34-10) was applied as $\mathrm{N}$ at $87 \mathrm{~kg} / \mathrm{ha}$, and six $\mathrm{Ca}\left(\mathrm{NO}_{3}\right)_{2}$ fertigation events were supplied as $\mathrm{N}$ at $16.8 \mathrm{~kg} / \mathrm{ha}$ each on 24 June; 1, 15, and 29 July; and 5 and 12 August.

The Henderson County trial was initiated on 9 June 2009. Fruit was harvested on 27 August and 3, 10, and 17 September. All fruit were harvested and graded as marketable or nonmarketable based upon the appearance of fruit shriveling, blossom-end rot, insect damage, severe fruit cracking, or size (i.e., too small), and fruit weight and number were recorded for each grade. On the final date, all fruit larger than $5 \mathrm{~cm}$ were harvested and recorded.

Statistical analyses. Data collected from all research trials were analyzed in the same manner but independently by trial. An area under the disease progress curve (AUDPC) was calculated (38) based on repeated measurements of the incidence of plants with 
bacterial wilt symptoms. AUDPC values and yield data were analyzed using the MIXED procedure of SAS, and an estimate of the means was generated using LSMEANS (SAS version 9.1; SAS Institute, Cary, NC). Where significant treatment effects occurred, Tukey's mean comparison test was utilized. In order to determine the effect of AUDPC values on marketable and total fruit yield, the CORR procedure was performed using the data gathered from all treatments within a given trial. The REG procedure was also carried out to determine an $R^{2}$ value that described the variance in total fruit yield which was accounted for by variance in the corresponding AUDPC values.

\section{Results}

Sampson County trial. At the Sampson County location, the incidence of bacterial wilt caused by $R$. solanacearum was high, particularly in the late period of the season ( $>80$ days after planting), and the effect of grafting with interspecific rootstocks on bacterial wilt AUDPC values was significant $(P<0.01$; Table 1$)$. Bacterial wilt incidence was less than $10 \%$ until 75 days after planting for non- and self-grafted plants, and the final mean bacterial wilt incidence was 100 and $82 \pm 15 \%$, respectively (Fig. 1A). Celebrity plants grafted onto Dai Honmei rootstocks had a final mean bacterial wilt incidence of $50 \pm 3 \%$ (Fig. 1A). Conversely, plants grafted onto RST-04-105-T rootstocks showed no symptoms of bacterial wilt (Fig. 1A). The AUDPC values reflected a similar trend suggesting that, over the course of the season, Dai Honmei and RST-04-105-T rootstocks provided moderate and high levels of protection against bacterial wilt, respectively $(P<0.05$; Fig. 1B).

Total and marketable fruit yield were significantly negatively correlated with bacterial wilt AUDPC values $(P<0.05$;

Table 1. Analyses of variance $P$ values of grafting onto resistant rootstocks on yield and area under the disease progress curve (AUDPC) values in three tomato trials performed in North Carolina ${ }^{\mathrm{z}}$

\begin{tabular}{|c|c|c|c|c|c|c|c|c|}
\hline \multirow[b]{2}{*}{ Location } & \multirow[b]{2}{*}{ Year } & \multicolumn{3}{|c|}{ Marketable fruit yield } & \multicolumn{3}{|c|}{ Total fruit yield } & \multirow[b]{2}{*}{ AUDPC } \\
\hline & & Weight (t/ha) & Size (g) & Number $\left(10^{3} / \mathrm{ha}\right)$ & Weight (t/ha) & Size (g) & Number $\left(10^{3} / \mathrm{ha}\right)$ & \\
\hline Sampson County & 2007 & 0.072 & 0.030 & 0.286 & 0.032 & 0.054 & 0.237 & 0.003 \\
\hline Jackson County & 2009 & 0.008 & 0.432 & 0.055 & 0.008 & 0.137 & 0.074 & $<0.001$ \\
\hline Henderson County & 2009 & $<0.001$ & 0.003 & $<0.001$ & $<0.001$ & $<0.001$ & $<0.001$ & $<0.001$ \\
\hline
\end{tabular}

${ }^{\mathrm{z}}$ Listed $P$ values were determined using the GLM procedure in SAS (version 9.1; SAS Institute, Cary, NC). AUDPC values were calculated (38) based on the incidence of bacterial wilt caused by Ralstonia solanacearum, as described in the main text.
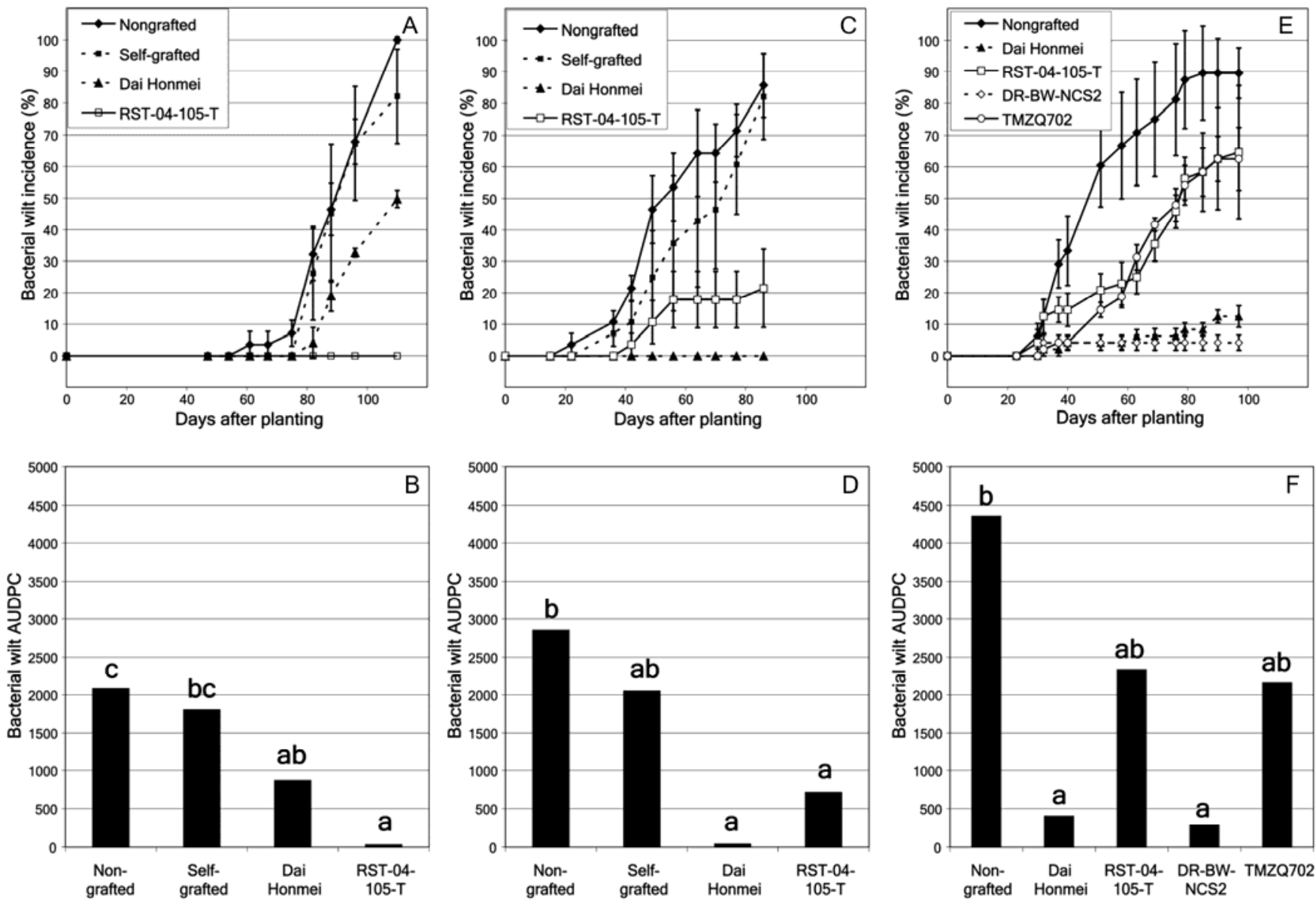

Fig. 1. Bacterial wilt (Ralstonia solanacearum) incidence and area under the disease progress curve (AUDPC) values for three trials in North Carolina with grafted tomato plants. A, Mean bacterial wilt incidence and B, AUDPC of non- and self-grafted 'Celebrity' tomato plants as well as Celebrity grafted onto 'Dai Honmei' and 'RST-04-105-T' rootstock at the Sampson County trial in 2007. C, Mean bacterial wilt incidence and D, AUDPC of non- and self-grafted 'Mountain Fresh' tomato plants as well as Mountain Fresh grafted onto Dai Honmei and RST-04-105-T rootstocks at the Jackson County trial in 2009. E, Mean bacterial wilt incidence and F, AUDPC of non- and self-grafted Mountain Fresh tomato plants as well as Mountain Fresh grafted onto Dai Honmei, RST-04-105-T, 'DR-BW-NCS2', and 'TMZQ702' rootstocks at the Henderson County trial in 2009. Each data point within the disease progress curves (A, C, and D) represent the observed mean of four replications. Each error bar represents the standard error of the mean. Within each trial, mean AUDPC values $(B, D$, and $F)$ each represent the mean of four replications and values with the same letters are not significantly different based on Tukey's mean comparison test $(\alpha=0.05)$. 
$\left.R_{\text {Marketable yield }}^{2}=0.4872 ; R_{\text {Total yield }}^{2}=0.4048\right)$. The reduced incidence of bacterial wilt for the grafted plants versus non- or self-grafted plants, in conjunction with the significant correlation between AUDPC values, indicated that the resistance of the rootstocks significantly increased fruit yield. The effect of grafting on total fruit yield was significant $(P<0.05$; Table 1$)$. Dai Honmei increased total fruit yield by $30 \%$ compared with nongrafted plants but this effect was not significant $(P<0.05)$. In contrast, RST-04$105-\mathrm{T}$ rootstock increased yield by $78 \%$ and this effect was significant $(P<0.05$; Table 2$)$.

Jackson County trial. In the Jackson County trial, bacterial wilt symptoms were observed earlier than in the Sampson County trial and had a greater effect on fruit yield. Among the nongrafted plants, the bacterial wilt incidence increased to greater than $10 \%$ 36 days after planting (Fig. 1C), and bacterial wilt AUDPC values were significantly impacted by grafting $(P<0.001$; Table 1$)$. Bacterial wilt incidence for the non- and self-grafted plants was 54 \pm 11 and $36 \pm 21 \% 56$ days after planting and the final mean bacterial wilt incidence was $86 \pm 10$ and $82 \pm 14 \%$, respectively (Fig. 1C). Mountain Fresh plants grafted onto RST-04-105-T rootstocks had lower incidences of bacterial wilt compared with the nongrafted plants throughout the season, with a final mean bacterial wilt incidence of $21 \pm 12 \%$ (Fig. 1C). Plants grafted with Dai Honmei rootstocks showed no symptoms of bacterial wilt (Fig. 1C). The AUDPC values reflected that, over the course of the season, Dai Honmei and RST-04-105-T rootstocks provided protection from the pathogen, and the bacterial wilt outbreak was significantly reduced by the deployment of the resistant rootstocks compared with the nongrafted controls $(P<0.05$; Fig. 1D). In this trial, the self-grafted plants showed slightly delayed symptoms compared to nongrafted plants (Fig. 1C) and had statistically similar bacterial wilt AUDPC values to the rootstocks (Fig. 1D).

At the trial in Jackson County, marketable and total fruit yield were significantly negatively correlated with bacterial wilt AUDPC values $\left(P<0.001 ; R^{2}\right.$ Marketable yield $=0.6914 ; R^{2}$ Total yield $\left.=0.6426\right)$. The significant correlation in conjunction with the relatively high $R^{2}$ Total yield value indicated that bacterial wilt had a significant effect on fruit production by reducing yield of plants in the "susceptible" treatments. In this trial, the outbreak of bacterial wilt was initiated earlier than in the trial in Sampson County and, at first fruit harvest (64 days after planting), non- and self-grafted plants had $64 \pm 14$ and $43 \pm 21 \%$ mean bacterial wilt incidence, respectively (Fig. 1C).
The effect of grafting on total and marketable fruit production was highly significant at the Jackson County trial $(P<0.01$; Table 1 ), and mean yield increases among marketable and total fruit yield data were 31 to $103 \%$ (Table 3). Plants grafted onto Dai Honmei had the greatest yields, with the mean marketable fruit yield increased by $103 \%$ compared with the nongrafted plants $(P<0.05$; Table 3). Plants grafted with RST-04-105-T rootstocks had 31\% greater mean total fruit yield than the nongrafted plants but this effect was not significant $(P<0.05$; Table 3$)$.

Henderson County trial. In the Henderson County trial, the bacterial wilt epidemic was particularly severe, as indicated by the early onset as well as the greater mean bacterial wilt AUDPC values compared with those measured in the other two trials. The bacterial wilt outbreak began 30 days after planting and, at first fruit harvest (79 days after planting), $88 \pm 15 \%$ of the nongrafted plants had been killed by $R$. solanacearum (Fig. 1E). Grafting had a significant effect on bacterial wilt AUDPC values $(P<0.001$; Table 1). Among the four rootstocks tested in the Henderson County trial, Dai Honmei and DR-BW-NCS2 resulted in the least amount of disease throughout the season, and final mean bacterial wilt incidence of plants with these two rootstocks was $13 \pm 3$ and 4 $\pm 2 \%$, respectively (Fig. 1E). This reduction in bacterial wilt incidence resulted in decreased bacterial wilt AUDPC values compared with the nongrafted plants $(P<0.05$; Fig. 1F). RST-04-105-T and TMZQ702 rootstocks also delayed the onset of disease but final mean bacterial wilt incidence was $65 \pm 21$ and $63 \pm 10 \%$ (Fig. 1E), and bacterial wilt AUDPC values were not significantly different than those of the nongrafted plants $(P<0.05$; Fig. 1F).

Marketable and total fruit yield were significantly negatively correlated with bacterial wilt AUDPC values $(P<0.001)$, and a large portion of the variability in marketable and total fruit yield was accounted for by bacterial wilt AUDPC values in this trial $\left(R^{2}\right.$ Marketable yield $=0.8552 ; R^{2}$ Total yield $\left.=0.8034\right)$. Similarly to the Jackson County trial, the greater $R^{2}$ values for AUDPC versus fruit yield indicated that the incidence of disease throughout the year accounted for some of the differences in fruit yield among the treatments. In this trial, the outbreak of bacterial wilt initiated earlier than at the other two locations, and the rapid increase in bacterial wilt incidence that occurred prior to first harvest might explain the severe reduction in fruit yield of plants in the "susceptible" treatments in this trial (Fig. 1E).

The effect of grafting on total and marketable fruit production was highly significant $(P<0.01$; Table 1$)$ and mean yield increases

Table 2. Tomato fruit yield of grafted and nongrafted 'Celebrity' at a Sampson County, NC trial site in 2007y

\begin{tabular}{|c|c|c|c|c|c|c|}
\hline \multirow[b]{2}{*}{ Cultivar } & \multicolumn{3}{|c|}{ Marketable fruit yield } & \multicolumn{3}{|c|}{ Total fruit yield } \\
\hline & Weight (t/ha) & Size (g) & Number $\left(10^{3} / \mathrm{ha}\right)$ & Weight (t/ha) & Size (g) & Number $\left(10^{3} / \mathrm{ha}\right)$ \\
\hline Nongrafted & $39.1 \mathrm{a}$ & $168 \mathrm{a}$ & $232.5 \mathrm{a}$ & $62.4 \mathrm{a}$ & 157 a & $397.4 \mathrm{a}$ \\
\hline Self-grafted & $43.9 \mathrm{a}$ & $180 \mathrm{ab}$ & $248.1 \mathrm{a}$ & $67.9 \mathrm{ab}$ & $166 \mathrm{ab}$ & $412.7 \mathrm{a}$ \\
\hline Dai Honmei ${ }^{\mathrm{z}}$ & $47.4 \mathrm{a}$ & $184 a b$ & $257.1 \mathrm{a}$ & $81.3 \mathrm{ab}$ & $177 \mathrm{ab}$ & $490.3 \mathrm{a}$ \\
\hline RST-04-105z & $64.7 \mathrm{a}$ & $202 \mathrm{~b}$ & $319.1 \mathrm{a}$ & $110.8 \mathrm{~b}$ & $192 \mathrm{~b}$ & $581.6 \mathrm{a}$ \\
\hline
\end{tabular}

y Grown under moderate disease pressure from bacterial wilt (Ralstonia solanacearum). Data were analyzed using the GLM procedure in SAS (version 9.1; SAS Institute; Cary, NC) and the means were compared with Tukey's mean separation test $(\alpha=0.05)$. Values followed by the same letter are not significantly different.

${ }^{\mathrm{z}}$ Commercial rootstocks grafted with Celebrity scion.

Table 3. Tomato fruit yield of grafted and nongrafted 'Mountain Fresh' at a Jackson County, NC trial site in 2009y

\begin{tabular}{|c|c|c|c|c|c|c|}
\hline \multirow[b]{2}{*}{ Cultivar } & \multicolumn{3}{|c|}{ Marketable fruit yield } & \multicolumn{3}{|c|}{ Total fruit yield } \\
\hline & Weight (t/ha) & Size (g) & Number $\left(10^{3} / \mathrm{ha}\right)$ & Weight (t/ha) & Size (g) & Number $\left(10^{3} / \mathrm{ha}\right)$ \\
\hline Nongrafted & $13.0 \mathrm{a}$ & $114 \mathrm{a}$ & $114.8 \mathrm{a}$ & $13.1 \mathrm{a}$ & $106 \mathrm{a}$ & $124.0 \mathrm{a}$ \\
\hline Self-grafted & $14.6 \mathrm{a}$ & $119 \mathrm{a}$ & $120.5 \mathrm{a}$ & $14.6 \mathrm{a}$ & $115 \mathrm{a}$ & $124.0 \mathrm{a}$ \\
\hline Dai Honmei ${ }^{z}$ & $26.5 \mathrm{~b}$ & $126 \mathrm{a}$ & 209.6 a & $26.5 \mathrm{~b}$ & $126 \mathrm{a}$ & 209.6 a \\
\hline RST-04-105 z & $17.1 \mathrm{ab}$ & $111 \mathrm{a}$ & $156.8 \mathrm{a}$ & $17.2 \mathrm{ab}$ & $111 \mathrm{a}$ & $157.4 \mathrm{a}$ \\
\hline
\end{tabular}

y Grown under moderate disease pressure from bacterial wilt (Ralstonia solanacearum). Data were analyzed using the GLM procedure in SAS (version 9.1; SAS Institute; Cary, NC) and the means were compared with Tukey's mean separation test $(\alpha=0.05)$. Values followed by the same letter are not significantly different.

${ }^{\mathrm{z}}$ Commercial rootstocks grafted with Mountain Fresh scion. 
were 68 to $332 \%$ among the four rootstocks tested compared with the nongrafted plants (Table 4). Plants grafted with DR-BW-NCS2 rootstocks had the greatest fruit yield but these yields were not significantly different than those of plants grafted with Dai Honmei rootstock. The mean total and marketable fruit yield of DR-BWNCS2 was 260 and $332 \%$ greater than that of nongrafted plants, respectively $(P<0.05$; Table 4$)$. Mountain Fresh plants with Dai Honmei rootstocks had $231 \%$ greater mean total fruit yield than the nongrafted plants $(P<0.05$; Table 4). RST-04-105-T- and TMZQ702-grafted plants had 128 and $72 \%$ greater mean fruit yield, respectively, than the nongrafted Mountain Fresh plants but these differences were not significant $(P<0.05$; Table 4$)$.

\section{Discussion}

In severely infested soils, $R$. solanacearum has the ability to dramatically reduce tomato fruit yield $(3,13)$, and grafting with resistant rootstocks can provide an effective tool to reduce yield losses caused by this pathogen. In this study, marketable and total fruit yield were significantly negatively correlated with bacterial wilt AUDPC values. Grafting with rootstocks RST-04-105-T, Dai Honmei, and DR-BW-NCS2 rootstocks significantly reduced AUDPC values compared with nongrafted plants across multiple locations. Interestingly, RST-04-105-T and Dai Honmei rootstocks conferred high and moderate resistance levels, respectively, in Sampson County, whereas the opposite was seen in Jackson County, and RST-04-105-T had similar levels of bacterial wilt as nongrafted plants at the Henderson County trial.

The diversity of $R$. solanacearum strains worldwide has led to the development of resistant tomato cultivars that are not durable over diverse geographic regions (36) and, based on the results of this study, significant diversity may exist across the different geographic locations evaluated in North Carolina. In Sampson County, there is a long history ( $>200$ years) of tobacco and vegetable crop production, and $R$. solanacearum has been indigenous in this area for a while, as indicated by early reports of bacterial wilt $(5,19)$. In contrast, bacterial wilt is an emerging issue in the mountain growing region of western North Carolina, including Jackson and Henderson Counties (F. J. Louws, personal observation). Recent studies suggest that new strains of $R$. solanacearum that are entering the United States may be poorly characterized (27), and a new strain has been of significant interest in Florida (18). Future work that seeks to characterize $R$. solanacearum strains and identify the impact of the pathogen population on the efficacy of tomato rootstocks will likely be of value to tomato growers in the United States.

Although the level of resistance to bacterial wilt observed among rootstocks evaluated in this study was not consistent across three locations in North Carolina, the results of this study suggest that Dai Honmei and RST-04-105-T can provide significant protection against severe crop failures caused by bacterial wilt. Other tomato rootstocks have shown efficacy worldwide against bacterial wilt $(11,24,25,30,39)$ but little information is available regarding the specific rootstocks utilized in those trials and most of the rootstocks are not commercially available for growers in the United States. In a recent preliminary report from the Eastern shore of
Virginia (10), RST-04-105-T performed poorly, similarly to the Henderson County trial in this report but opposite to the Sampson and Jackson County trials.

The partial resistance to bacterial wilt seen in this study and others (10) could complement other integrated pest management strategies to reduce bacterial wilt incidence in severely infested soils. For example, the plant activator acibenzolar- $S$-methyl can be used to reduce bacterial wilt severity among moderately resistant cultivars (31). Other strategies that show quantitative efficacy against bacterial wilt $(1,2,4,17)$ could be combined with grafting to further reduce the incidence of bacterial wilt in severely infested soils.

Quantitative resistance to diseases and pests in wild Solanum spp. is often known by breeders but the utilization of this resistance can be problematic due to unwanted traits, such as small fruit size, being linked to resistance; this paradigm is particularly acute in the case of bacterial wilt $(29,40,41)$. Grafting can provide an effective management strategy to help reduce bacterial wilt incidence and subsequent crop loss. This study provides the first report of commercially available rootstock cultivars that growers in the southeastern United States can utilize by grafting to manage bacterial wilt in this region. Grafting is also effective at reducing damage and crop loss caused by other soilborne plant pathogens such as Fusarium oxysporum f. sp. lycopersici, Sclerotium rolfsii, and rootknot nematodes (Meloidogyne spp.), as demonstrated in recent field trials in North Carolina (33,34). However, the rootstocks utilized in those studies have no known or reported resistance to bacterial wilt. Although the findings of this study and other studies suggest that the use of resistant rootstocks will be an important component to an integrated pest management program for tomato, there are no rootstocks that are resistant to all pathogens. Therefore, the implementation of this technology will depend on research and extension personnel in the United States, because accurate disease diagnosis combined with rootstock selection that is based upon sound research is vital to successful use of grafting with resistant rootstocks. This study suggests that this paradigm is particularly evident for bacterial wilt, caused by $R$. solanacearum, and a better understanding of the dynamics of the pathogen diversity in combination with evaluation of host resistance in Solanum rootstocks will enhance the ability to reduce crop losses by this devastating disease of tomato.

\section{Acknowledgments}

Funding was provided by the Organic Farming Research Foundation, Southern Region SARE grants GS07-060 and LS06-193, and United States Department of Agriculture NIFA grant 2007-51106-03794. We thank the North Carolina State University (NCSU) Phytotron staff as well as M. Schiessl and A. McWhirt for technical assistance; C. Bredenkamp (North Caroline Cooperative Extension Service), P. Ojiambo (NCSU), H. D. Shew (NCSU), and E. L. Davis (NCSU); our on-farm collaborators S. Hartmann, K. Cochran, and the North Carolina Department of Agriculture staff at the Mountain Horticultural Crops Research and Extension Center (Mills River, NC); and De Ruiter Seeds, DP Seeds, Asahi Industries Co., and Sakata Seed for donations of rootstock seed.

\section{Literature Cited}

1. Adhikari, T. B., and Basnyat, R. C. 1998. Effect of crop rotation and cultivar resistance on bacterial wilt of tomato in Nepal. Can. J. Plant Pathol. 20:283-287.

Table 4. Tomato fruit yield of grafted and nongrafted 'Mountain Fresh' at a Henderson County, NC trial site in 2009y

\begin{tabular}{|c|c|c|c|c|c|c|}
\hline \multirow[b]{2}{*}{ Cultivar } & \multicolumn{3}{|c|}{ Marketable fruit yield } & \multicolumn{3}{|c|}{ Total fruit yield } \\
\hline & Weight (t/ha) & Size (g) & Number $\left(10^{3} / \mathrm{ha}\right)$ & Weight (t/ha) & Size (g) & Number $\left(10^{3} / \mathrm{ha}\right)$ \\
\hline Nongrafted & $11.0 \mathrm{a}$ & $191 \mathrm{a}$ & $48.0 \mathrm{a}$ & $17.3 \mathrm{a}$ & $99 \mathrm{a}$ & $134.5 \mathrm{a}$ \\
\hline Dai Honmei ${ }^{z}$ & $40.6 \mathrm{ab}$ & $256 \mathrm{~b}$ & $158.5 \mathrm{ab}$ & $57.3 \mathrm{~b}$ & $224 \mathrm{ab}$ & $255.3 \mathrm{a}$ \\
\hline RST-04-105z & $30.1 \mathrm{ab}$ & $221 \mathrm{ab}$ & $128.9 \mathrm{ab}$ & $39.5 \mathrm{ab}$ & $156 \mathrm{a}$ & $233.5 \mathrm{a}$ \\
\hline DR-BW-NCS2 ${ }^{z}$ & $47.5 \mathrm{~b}$ & $256 \mathrm{~b}$ & $184.8 \mathrm{~b}$ & $62.2 \mathrm{~b}$ & $232 \mathrm{bc}$ & $268.2 \mathrm{a}$ \\
\hline TMZQ702 & $18.5 \mathrm{ab}$ & $228 \mathrm{ab}$ & $80.1 \mathrm{ab}$ & $29.7 \mathrm{ab}$ & $159 \mathrm{abc}$ & $185.1 \mathrm{a}$ \\
\hline
\end{tabular}

y Grown under severe disease pressure from bacterial wilt (Ralstonia solanacearum). Data were analyzed using the GLM procedure in SAS (version 9.1; SAS Institute; Cary, NC) and the means were compared with Tukey's mean separation test $(\alpha=0.05)$. Values followed by the same letter are not significantly different.

${ }^{\text {z }}$ Commercial rootstocks were grafted with Mountain Fresh scion. 
2. Baptista, M. J., Reis, F. B., Xavier, G. R., de Alcantara, C., de Oliveira, A.R., Souza, R. B., and Lopes, C. A. 2007. Efficiency of solarization and biofumigation on tomato bacterial wilt control in the field. Pesqui. Agropecu. Bras. 42:933-938.

3. Buddenhagen, I., and Kelman, A. 1964. Biological and physiological aspects of bacterial wilt caused by Pseudomonas solanacearum. Annu. Rev. Phytopathol. 2:203-230.

4. Chellemi, D. O. 2002. Nonchemical management of soilborne pests in fresh market vegetable production systems. Phytopathology 92:1367-1372.

5. Clayton, E. E., and Smith, T. E. 1942. Resistance of tobacco to bacterial wilt (Bacterium solanacearum). J. Agric. Res. 65:0547-0554.

6. di Bisceglie, D. P., Saccardi, A., Giosue, S., Traversa, F., and Mazzucchi, U. 2005. Survival of Ralstonia solanacearum on wood, high density polyethylene and on jute fabric in cold storage. J. Plant Pathol. 87:145-147.

7. Driver, J., and Louws, F. J. 2002. Fumigants and varieties to manage southern bacterial wilt of tomato. Pages 228-232 in: 2002 Annu. Int. Res. Conf. Methyl Bromide Alternatives Emissions Reductions. Orlando, FL

8. Enfinger, J. M., McCarter, S. M., and Jaworski, C. A. 1979. Evaluation of chemicals and application methods for control of bacterial wilt of tomato transplants. Phytopathology 69:637-640.

9. Fegan, M., and Prior, P. 2005. How complex is the "Ralstonia solanacearum complex"? Pages 449-462 in: Bacterial Wilt Disease and the Ralstonia solanacearum Species Complex. C. Allen, P. Prior, and A. C. Hayward, eds. American Phytopathological Society, St. Paul, MN.

10. Freeman, J., Rideout, S., and Wimer, A. 2009. Performance of grafted tomato seedlings in open-field production. Pages 45-41 to 45-42 in: 2009 Annu. Int. Res. Conf. Methyl Bromide Alternatives Emissions Reductions. San Diego, CA.

11. Grimault, V., and Prior, P. 1994. Grafting tomato cultivars resistant or susceptible to bacterial wilt-analysis of resistance mechanisms. J. Phytopathol. 141:330-334.

12. Hanson, P. M., Wang, J. F., Licardo, O., Hanudin, Mah, S. Y., Hartman, G. L., Lin, Y. C., and Chen, J. T. 1996. Variable reaction of tomato lines to bacterial wilt evaluated at several locations in Southeast Asia. HortScience 31:143-146.

13. Hayward, A. 1991. Biology and epidemiology of bacterial wilt caused by Pseudomonas solanacearum. Annu. Rev. Phytopathol. 29:65-87.

14. Hayward, A. C. 1964. Characteristics of Pseudomonas solanacearum. J. Appl. Bacteriol. 27:265-277.

15. Husain, A., and Kelman, A. 1958. Relation of slime production to mechanism of wilting and pathogenicity of Pseudomonas solanacearum. Phytopathology 48:155-165.

16. Ivors, K. 2010. Commercial production of staked tomatoes in the southeast. N. C. Coop. Ext. Serv. Bull. AG-405 3rd ed.

17. Ji, P., Momol, M. T., Olson, S. M., Pradhanang, P. M., and Jones, J. B. 2005. Evaluation of thymol as a biofumigant for control of bacterial wilt of tomato under field conditions. Plant Dis. 89:497-500.

18. Ji, P.S., Allen, C., Sanchez-Perez, A., Yao, J., Elphinstone, J. G., Jones, J. B., and Momol, A. T. 2007. New diversity of Ralstonia solanacearum strains associated with vegetable and ornamental crops in Florida. Plant Dis. 91:195-203.

19. Kelman, A. 1953. The bacterial wilt caused by Pseudomonas solanacearum. N. C. Agric. Exp. Stn. Tech. Bull. 99:194.

20. Kelman, A. 1954. The relationship of pathogenicity in Pseudomonas solanacearum to colony appearance on a tetrazolium medium. Phytopathology 44:693-695.

21. Kelman, A. 1998. One hundred and one years of research on bacterial wilt. Pages 1-6 in: Bacterial Wilt Disease: Molecular and Ecological Aspects. P. Prior, C. Allen, and J. Elphinstone, eds. Springer, Verlag, Berlin.
22. King, S. R., Davis, A. R., Liu, W. G., and Levi, A. 2008. Grafting for disease resistance. HortScience 43:1673-1676.

23. Lemaga, B., Kanzikwera, R., Kakuhenzire, R., Hakiza, J., and Maniz, G. 2001. The effect of crop rotation on bacterial wilt incidence and potato tuber yield. Afr. Crop Sci. 9:257-266.

24. Lin, C., Hsu, S., Tzeng, K., and Wang, J. 2008. Application of a preliminary screen to select locally adapted resistant rootstock and soil amendment for integrated management of tomato bacterial wilt in Taiwan. Plant Dis. 92:909-916.

25. Matsuzoe, N., Okubo, H., and Fujieda, K. 1993. Resistance of tomato plants grafted on Solanum rootstocks to bacterial wilt and root-knot nematode. J. Jpn. Soc. Hortic. Sci. 61:865-872.

26. McCarter, S. 1991. Bacterial wilt. Pages 28-29 in: Compendium of Tomato Diseases. J. B. Jones, J. P. Jones, R. E. Stall, and T. Zitter, eds. American Phytopathological Society, St. Paul, MN.

27. Norman, D. J., Zapata, M., Gabriel, D. W., Duan, Y. P., Yuen, J. M. F., Mangravita-Novo, A., and Donahoo, R. S. 2009. Genetic diversity and hos range variation of Ralstonia solanacearum strains entering North America. Phytopathology 99:1070-1077.

28. O'Connell, S., Hartmann, S., Rivard, C. L., Peet, M. M., and Louws, F. J. 2009. Grafting tomatoes on disease resistant rootstocks for small-scale organic production. http://ofrf.org/funded/highlights/oconnell_07f30.html

29. Opena, R., Hartman, G. L., Chen, J., and Yang, C. 1990. Breeding for bacterial wilt resistance in tropical tomato. Pages 44-50 in: 3rd Int. Conf. Plant Prot. Trop. Genting Highlands, Malaysia.

30. Peregrine, W. T. H., and Binahmad, K. 1982. Grafting - a simple technique for overcoming bacterial wilt in tomato. Trop. Pest Manage. 28:7176.

31. Pradhanang, P. M., Ji, P., Momol, M. T., Olson, S. M., Mayfield, J. L., and Jones, J. B. 2005. Application of acibenzolar-S-methyl enhances host resistance in tomato against Ralstonia solanacearum. Plant Dis. 89:989-993.

32. Rivard, C. L., and Louws, F. J. 2006. Grafting for disease resistance in heirloom tomatoes. N. C. Coop. Ext. Serv. Bull. AG-675.

33. Rivard, C. L., and Louws, F. J. 2008. Grafting to manage soilborne diseases in heirloom tomato production. HortScience 43:2104-2111.

34. Rivard, C. L., O'Connell, S., Peet, M. M., and Louws, F. J. 2010. Grafting tomato with inter-specific rootstock provides effective management against diseases caused by $S$. rolfsii and southern root-knot nematodes. Plant Dis. 94:1015-1021.

35. Satou, M., Kubota, M., and Nishi, K. 2006. Measurement of horizontal and vertical movement of Ralstonia solanacearum in soil. J. Phytopathol. 154:592-597.

36. Scott, J. W. 1996. Tomato improvement for bacterial disease resistance for the tropics: a contemporary basis and future prospects. Pages 117-123 in: 1st Int. Symp. Trop. Tomato Dis. Recife, Pemambuco, Brazil.

37. Scott, J. W., Wang, J., and Hanson, P. 2005. Breeding tomatoes for resistance to bacterial wilt, a global view. Pages 161-172 in: 2005 Int. Symp. Tomato Dis. Orlando, FL

38. Shaner, G., and Finney, R. E. 1977. Effect of nitrogen-fertilization on expression of slow-mildewing resistance in knox wheat. Phytopathology 67:1051-1056.

39. Tikoo, S. K., Mathai, P. J., and Kishan, R. 1979. Successful graft culture of tomato in bacterial wilt sick soils. Curr. Sci. 48:259-260.

40. Walter, J. M. 1967. Hereditary resistance to disease in tomato. Annu. Rev. Phytopathol. 5:131-160.

41. Wang, J. F., Hanson, P., and Barnes, J. 1998. Worldwide evaluation of an international set of resistance sources to bacterial wilt in tomato. Pages 269 275 in: Bacterial Wilt Disease: Molecular and Ecological Aspects. P. Prior, C. Allen, and J. Elphinstone, eds. Springer, Verlag, Berlin. 